\title{
Bibliometric analysis of interventional literature on mobile health: The most highly cited articles
}

\author{
Arefeh Ameri ${ }^{1}$ (D), Farzad Salmanizadeh ${ }^{1}$ (iD) Kambiz Bahaadinbeigy ${ }^{2 *(i D)}$ \\ ${ }^{1}$ Ph.D. Student in Medical Informatics, Department of Health Information Technology, Faculty of Management and Medical Informatics, Kerman \\ University of Medical Sciences, Kerman, Iran \\ ${ }^{2}$ Associate Professor, Medical Informatics Research Center, Institute for Futures Studies in Health, Kerman University of Medical Sciences, \\ Kerman, Iran
}

\begin{tabular}{|c|c|}
\hline Article Info & A B S T R A C T \\
\hline $\begin{array}{l}\text { Article type: } \\
\text { Review }\end{array}$ & \multirow{3}{*}{$\begin{array}{l}\text { Introduction: Advances in mobile health have led to numerous relevant } \\
\text { studies in diagnosis, treatment, and controlling of various diseases. One of } \\
\text { the criteria indicating the quality of the previously published studies is the } \\
\text { number of citations. Therefore, investigating the features of highly cited } \\
\text { articles and identifying the most frequently used mobile technological } \\
\text { interventions can affect future research ideas. This study aimed at } \\
\text { identifying } 100 \text { highly cited interventional studies on mobile health, type of } \\
\text { used mobile technologies, and effect of these technologies in various } \\
\text { diseases in top-cited articles. }\end{array}$} \\
\hline $\begin{array}{l}\text { Article History: } \\
\text { Received: 2020-12-04 } \\
\text { Accepted: 2021-02-06 } \\
\text { Published: 2021-03-08 }\end{array}$ & \\
\hline & \\
\hline $\begin{array}{l}\text { Associate Professor, Medical } \\
\text { Informatics Research Center, } \\
\text { Institute for Futures Studies in } \\
\text { Health, Kerman University of } \\
\text { Medical Sciences, Kerman, Iran }\end{array}$ & $\begin{array}{l}\text { Material and Methods: The database employed in this study was the Web } \\
\text { of Science, which without limitations was analysed in April } 2020 \text { to identify } \\
100 \text { highly cited interventional studies in the field of mobile health. The } \\
\text { identified studies were classified based on the number of citations, year of } \\
\text { publication, country of the first author, type of disease, and use of mobile } \\
\text { technology. }\end{array}$ \\
\hline Email: kambizb321@gmail.com & \multirow{3}{*}{$\begin{array}{l}\text { Results: A great majority of the studies in the field of interventional mobile } \\
\text { health focused on obesity }(n=18) \text {, addiction }(n=15) \text {, diabetes }(n=13) \text { and } \\
\text { mental health disorders }(n=12) \text {, respectively. Many studies employed } \\
\text { mobile technologies to promote lifestyle (weight loss and increased physical } \\
\text { activity) }(n=20) \text {, disease controls }(n=20) \text {, and treatment adherence ( } n=18) \text {. } \\
\text { The mean number of citations per study was } 146 \pm 97 \text {. The most cited study } \\
\text { was in the category of viral disease treatment adherence }(n=703) \text {, and the } \\
\text { most cited articles were published in } 2012 \text {. } \\
\text { Conclusion: Among the reviewed } 100 \text { studies, many of the interventional } \\
\text { studies regarding mobile health focused on obesity, addiction, diabetes and } \\
\text { mental health disorders. Promotion of lifestyle, disease controls, and } \\
\text { treatment adherence were effects of mobile technologies in top-cited } \\
\text { articles. Text messaging service was used as intervention in most of the } \\
\text { studies. Thus, future studies may focus on the use of various mobile } \\
\text { applications on different diseases' prevention, control, and treatment. }\end{array}$} \\
\hline $\begin{array}{l}\text { Keywords: } \\
\text { Telemedicine } \\
\text { Mobile Health } \\
\text { Top Cited } \\
\text { Publications } \\
\text { Bibliometric }\end{array}$ & \\
\hline & \\
\hline
\end{tabular}

Cite this paper as:

Ameri A, Salmanizadeh F, Bahaadinbeigy K. Bibliometric Analysis of Interventional Literature on Mobile Health: The Most Highly Cited Articles. Front Health Inform. 2021; 10: 66. DOI: 10.30699/fhi.v10i1.262

\section{INTRODUCTION}

The emergence of mobile devices in the 1990s allowed physicians easier access to medical records, test results, medical imaging and pharmaceutical information [1]. Moreover, through using this technology, patients can be diagnosed and monitored at any time and place via a mobile telephone [1]. Therefore, the use of this technology in the field of health service has created the term 'mobile health'
('M-health'). Mobile health can be defined as the use of mobile technologies to provide each individual with health care services at any time and place by removing spatial and time limitations [2]. A great number of health care problems could be resolved by using mobile health to access health care, make decisions, and manage chronic and critical conditions [2] .

Mobile health uses a combination of mobile 
telephone potential and other mobile technologies, such as telephone calls, short message service (SMS) and mobile applications, to provide health, medical and educational services [1]. The various capabilities of mobile health in increasing remote monitoring of patients have laid the ground for numerous investments []‥ According to Statista's report, by 2021, the global mobile health market will grow to nearly $\$ 100$ billion [4]. This provides many opportunities to prepare efficient mobile health solutions. As a result, advances in the implementation of mobile health techniques have been concurrent with numerous studies investigating the diverse capabilities of mobile health for disease prevention, control and treatment $[\underline{2}, \underline{5}]$. One of the indices of quality assessment of these previously published articles is their number of citations. Citation occurs when one scientific article uses another as a reference. The more times an article is cited, the more valuable is that article [].

Highly cited articles can be reviewed with the purpose of identifying the type and place of research, showing the progress of texts over time, determining the most cited areas and countries, helping researchers and students identify new areas to work on, identifying the most contributing authors in this field and determining the organizational affiliation of the authors [-10]. Recently, ISI introduced the newest journal citation system, Science Citation Index $\AA$ (SCI) Expanded, which is one of the databases available in the Web of Science (WOS) portal. Through using the citation data retrieved from WOS databases, researchers have identified and analysed highly cited articles in different areas, such as medical informatics, telemedicine and other clinical sciences, including psychiatry, ophthalmology, anaesthesia, orthopaedics, rehabilitation and delivery [11-18]. In a bibliometric study, Sweileh et al. reviewed all published studies on mobile health between 2006 and 2016 [19]. However, as far as the authors of this article are aware, no study has yet reviewed 100 highly cited articles on mobile health interventions. Therefore, reviewing the features of highly cited articles on mobile health interventions, and determining the most widely used mobile technology interventions, as well as their capabilities and applicability, can affect future research ideas and real use of these technologies in various diseases and healthcare services. This work will also be useful to researchers and policy makers. Therefore, the present study aimed to identify 100 highly cited interventional articles in the field of mobile health and to address the following questions:

What are type of used mobile technologies in 100 highly cited interventional articles?

What are impact of mobile technology interventions in various diseases in top-cited articles?

\section{MATERIAL AND METHODS}

The present study is a bibliometric analysis of the most highly cited interventional articles on mobile health, using data obtained from the WOS in August 2020. The citation counts from resources such as Google Scholar, Scopus and WOS vary [미]. We chose WOS because we found it was the database providing the highest scientific quality. WOS has been shown to be the most robust scientific database resource for medicine [21]. Mobile health (M-health) is the term used to designate applications that support medicine and health services through mobile devices [22]. In this study, the search was conducted without any time limit in WOS (all years $=1900-2020$ ). The articles were searched by word combination related to mobile health. The keywords were searched based on TS (topic) field. In WOS, the topic fields contain title, abstract, author, keywords and keywords plus ${ }^{\circledR}$ [23] :

TS = ("mobile health" OR "M health" OR "mobile application" OR "smartphone" OR "Mobile technology" OR "Mobile communication technology" OR “Text messag*”)

After searching the database, the extracted articles were sorted according to the number of citations (times cited).

\section{Inclusion criteria for articles}

The inclusion criteria were as follows. (1) The reviewed studies focused on mobile health interventions and other mobile technologies in healthcare. (2) We included interventional studies (e.g., randomised clinical trial, quasi-experimental studies, case studies, experimental pilot studies and quasi-experimental pilot studies) and excluded descriptive and qualitative studies. (3) The research articles had to be original articles, not review articles, conference presentations, and letters to the editor, short communications, reviews or case reports.

\section{Selection, data collection and analysis}

After performing the search, 26,834 articles were retrieved. The title and abstract of each article were studied and the articles that met all inclusion criteria were included. Based on previous studies [11, 13-16], we also selected 100 highly cited articles. To find the 100 top cited articles related to the purpose of the study, we evaluated 489 highly cited articles on the WOS database, and 100 cited articles that met all the inclusion criteria were included in Endnote X8.0.1. The bibliometric information and full text of the final articles were then reviewed. Each article was examined based on attributes such as journal name, journal impact factor, year of publication, geographic origin, total number of citations, and type of disease and performance of mobile technology. The information extracted from these articles was 
entered into Microsoft Excel 2018. The mean number of citations per article and the range of citations were calculated using SPSS 24.

\section{RESULTS}

In this study, to select 100 highly cited papers related to the purpose of the study, 484 highly cited articles were extracted from the WOS database. Then 100 highly cited articles related to the aims of the study were categorised by disease and the type of mobile technology employed in that study (Table 1). In the disease category, studies were divided according to the type of disease that the participants had and the affected body part. In this category, the greatest number of intervention articles in the field of health addressed obesity $(n=18)$, addiction $(n=15)$, diabetes $(n=13)$ and mental health disorders $(n=12)$, respectively. Studies in which the patients had multiple chronic diseases were categorised as 'general medicine'. Studies that used mobile technology interventions to lose weight and increase physical activity were categorised as impact on lifestyle'. Thus, in terms of the function of mobile technologies, most studies used this technology to enhance lifestyle $(n=20)$, control diseases $(n=20)$ and encourage adherence to treatment $(n=18)$ (Table 1).

Table 1: Classification of 100 highly cited interventional studies on mobile health by type of disease and performance of mobile technology

\begin{tabular}{|l|c|l|c|}
\hline Disease Categories & Number & Functionality Categories & Number \\
\hline Addiction & 15 & Alcohol addiction quitting & 3 \\
\hline Cancer & 3 & Detecting diseases & 5 \\
\hline Diabetes & 13 & Disease controls & 20 \\
\hline ENT diseases & 1 & Attendance/ Appointment reminders & 7 \\
\hline Eye diseases & 1 & Knowledge improvement & 2 \\
\hline Gynecology/obstetrics & 6 & Self-monitoring & 9 \\
\hline Heart diseases & 7 & Cigarette smoking quitting & 12 \\
\hline Infectious diseases & 3 & Treatment adherence & 18 \\
\hline Liver diseases & 2 & Vaccination reminders & 4 \\
\hline Mental health disorders & 12 & Impact on lifestyle & 20 \\
\hline Neurological disorders & 1 & Total & 100 \\
\hline Obesity & 18 & & \\
\hline Respiratory diseases & 4 & & \\
\hline Viral diseases & 8 & & \\
\hline General medicine & 5 & & \\
\hline Skin care & 1 & & \\
\hline Total & 100 & & \\
\hline
\end{tabular}

Table 2 presents the names of articles, number of citations and category of each article. The number of citations to the articles ranged between 84 and 740 . The mean number of citations per article was $153 \pm 100$. The most cited article was in the category of adherence to treatment and viral diseases [24] (Table 2).

Table 3 displays the name of the journal and its impact factor. The majority of articles were published in the Journal of Medical Internet Research $(n=9)$, while the most cited article in this study was published in 2010 in Lancet Journal [24]. The impact factor of the journals was between 0.954 and 59.102 , and the highest impact factor belonged to Lancet Journal.

Table 4 presents the countries of the first authors of the 100 most cited articles relevant to the objectives of the present study. The first authors of these articles were based in the United States $(n=45)$, Australia $(n=13)$, England $(n=11)$ and New Zealand $(n=6)$, respectively (Table 4 ).

This study covered 100 highly cited interventional studies on mobile health between 2002 and 2016, and the highest number of citations pertinent to the goal of this research was published in 2012 (Fig 1).

Table 2: One hundred highly cited interventional studies on mobile health

\begin{tabular}{|c|c|c|c|c|}
\hline $\begin{array}{l}\text { 류 } \\
\text { 류 }\end{array}$ & 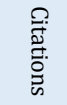 & Author(s)/ year & Disease Categories & Functionality Categories \\
\hline 1 & 740 & Lester et al., $2010[\underline{\underline{24}}]$ & Viral diseases & Treatment adherence \\
\hline 2 & 547 & Pop-Eleches et al., 2011 [25] & Viral diseases & Treatment adherence \\
\hline 3 & 434 & Rodgers et al., 2005 [26] & Addiction & Cigarette smoking quitting \\
\hline 4 & 430 & Free et al., 2011 [27] & Addiction & Cigarette smoking quitting \\
\hline
\end{tabular}




\begin{tabular}{|c|c|c|c|c|}
\hline $\begin{array}{l}\mathbb{N}_{0} \\
\text { 公 }\end{array}$ & 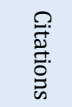 & Author(s)/ year & Disease Categories & Functionality Categories \\
\hline 5 & 388 & Patrick et al., 2009 [28] & Obesity & Impact on lifestyle \\
\hline 6 & 345 & Franklin et al., 2006 [29] & Diabetes & Disease controls \\
\hline 7 & 309 & Carter et al., 2013 [30] & Obesity & Impact on lifestyle \\
\hline 8 & 269 & Gustafson et al., 2014 [31] & Addiction & Alcohol addiction quitting \\
\hline 9 & 267 & Quinn et al., 2011 [32] & Diabetes & Self-monitoring \\
\hline 10 & 256 & Burns et al., 2011 [33] & Mental health disorders & Disease controls \\
\hline 11 & 248 & Chow et al., 2015 [34] & Heart diseases & Disease controls \\
\hline 12 & 212 & Zurovac et al., 2011 [35] & Infectious diseases & Treatment adherence \\
\hline 13 & 210 & Laksanasopin et al., 2015 [트] & Infectious diseases & Detecting diseases \\
\hline 14 & 206 & Stockwell et al., 2012 [37] & Respiratory diseases & Vaccination reminders \\
\hline 15 & 200 & Napolitano et al., 2013 [38] & Obesity & Impact on lifestyle \\
\hline 16 & 199 & Jakicic et al., 2016 [39] & Obesity & Impact on lifestyle \\
\hline 17 & 197 & Ben-Zeev et al., 2014 [ㅇ] & Mental health disorders & Disease controls \\
\hline 18 & 191 & Wolf et al., 2013 [41] & Cancer & Detecting diseases \\
\hline 19 & 190 & Obermayer et al., 2004 [42] & Addiction & Cigarette smoking quitting \\
\hline 20 & 182 & Strandbygaard et al., $2010[\underline{43}]$ & Respiratory diseases & Treatment adherence \\
\hline 21 & 182 & Leong et al., 2006 [44] & General medicine & Attendance/appointment reminders \\
\hline 22 & 174 & Hanauer et al., 2009 [45] & Diabetes & Disease controls \\
\hline 23 & 173 & Varnfield et al., 2014 [누] & Heart diseases & Disease controls \\
\hline 24 & 170 & Granholm et al., 2012 [47] & Mental health disorders & Treatment adherence \\
\hline 25 & 168 & Depp et al., 2010 [48] & Mental health disorders & Self-monitoring \\
\hline 26 & 167 & Haapala et al., 2009 [49] & Obesity & Impact on lifestyle \\
\hline 27 & 163 & Armstrong et al., 2009 [50] & Skin care & Treatment adherence \\
\hline 28 & 161 & Petrie et al., 2012 [51] & Respiratory diseases & Treatment adherence \\
\hline 29 & 161 & Wang et al., 2011 [ $\underline{52}]$ & Cancer & Detecting diseases \\
\hline 30 & 157 & Borland et al., 2013 [ $\underline{53}]$ & Addiction & Cigarette smoking quitting \\
\hline 31 & 153 & King et al., 2013 [54] & Obesity & Impact on lifestyle \\
\hline 32 & 150 & Watts et al., 2013 [55] & Mental health disorders & Disease controls \\
\hline 33 & 149 & Downer et al., 2005 [56] & General medicine & Attendance/appointment reminders \\
\hline 34 & 140 & Chen et al., 2008 [ $\underline{57}]$ & General medicine & Attendance/appointment reminders \\
\hline 35 & 140 & Kirwan et al., 2013 [됴] & Diabetes & Self-monitoring \\
\hline 36 & 139 & Bricker et al., 2014 [무] & Addiction & Cigarette smoking quitting \\
\hline 37 & 138 & Laing et al., 2014 [60] & Obesity & Impact on lifestyle \\
\hline 38 & 137 & Miloh et al., 2009 [61] & Liver diseases & Treatment adherence \\
\hline 39 & 135 & McManus et al., 2013 [62] & Heart diseases & Detecting diseases \\
\hline 40 & 133 & Kharbanda et al., 2011 [ $\underline{63}]$ & Viral diseases & Vaccination reminders \\
\hline 41 & 130 & Shapiro et al., 2008 [64] & Obesity & Self-monitoring \\
\hline 42 & 129 & Charpentier et al., 2011 [65] & Diabetes & Disease controls \\
\hline 43 & 128 & Gerber et al., 2009 [66] & Obesity & Impact on lifestyle \\
\hline 44 & 124 & Spring et al., 2012 [67] & Obesity & Impact on lifestyle \\
\hline 45 & 123 & Vervloet et al., 2012 [68] & Diabetes & Treatment adherence \\
\hline 46 & 123 & Mbuagbaw et al., 2012 [69] & Viral diseases & Treatment adherence \\
\hline 47 & 122 & Hardy et al., 2011 [70] & Viral diseases & Treatment adherence \\
\hline 48 & 121 & Suffoletto et al., 2012 [71] & Addiction & Alcohol addiction quitting \\
\hline 49 & 119 & Arora et al., 2015 [를 & Neurological disorders & Detecting diseases \\
\hline 50 & 117 & Koshy et al., 2008 [굴 & Eye diseases & Attendance/appointment reminders \\
\hline 51 & 116 & Dowshen et al., 2012 [74] & Viral diseases & Treatment adherence \\
\hline 52 & 115 & Haines et al., 2013 [75] & Obesity & Impact on lifestyle \\
\hline 53 & 113 & Rizvi et al., 2011 [흐] & Mental health disorders & Disease controls \\
\hline 54 & 113 & Glynn et al., 2014 [77] & Obesity & Impact on lifestyle \\
\hline 55 & 112 & Stockwell et al., 2012 [78] & Infectious diseases & Vaccination reminders \\
\hline 56 & 112 & Proudfoot et al., 2013 [국] & Mental health disorders & Disease controls \\
\hline 57 & 111 & da Costa et al., $2012[\underline{80}]$ & Viral diseases & Treatment adherence \\
\hline 58 & 110 & Hou et al., 2010 [81] & Gynecology/obstetrics & Treatment adherence \\
\hline 59 & 109 & Bopp et al., 2010 [르 & Mental health disorders & Disease controls \\
\hline 60 & 108 & Altice et al., 2007 [으] & Viral diseases & Treatment adherence \\
\hline 61 & 106 & Ryan et al., 2012 [요 & Respiratory diseases & Self-monitoring \\
\hline 62 & 105 & Franklin et al., 2008 [ㄷ] & Diabetes & Disease controls \\
\hline 63 & 105 & Spring et al., 2013 [으] & Obesity & Impact on lifestyle \\
\hline 64 & 104 & Riley et al., 2008 [87] & Addiction & Cigarette smoking quitting \\
\hline 65 & 103 & Kirwan et al., 2012 [요 & General medicine & Impact on lifestyle \\
\hline 66 & 103 & Istepanian et al., 2009 [우] & Diabetes & Disease controls \\
\hline 67 & 103 & Whittaker et al., 2008 [90] & Addiction & Cigarette smoking quitting \\
\hline 68 & 103 & Ferrer-Roca et al., 2004 [91] & Diabetes & Disease controls \\
\hline 69 & 103 & Baker et al., 2014 [므] & Cancer & Treatment adherence \\
\hline 70 & 101 & Wang et al., 2015 [93] & Obesity & Impact on lifestyle \\
\hline 71 & 99 & Gómez et al., 2002 [94] & Diabetes & Disease controls \\
\hline
\end{tabular}




\begin{tabular}{|c|c|c|c|c|}
\hline 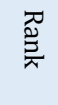 & 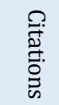 & Author(s)/ year & Disease Categories & Functionality Categories \\
\hline 72 & 99 & Lund et al., 2014 [95] & Gynecology/obstetrics & Attendance/ Appointment reminders \\
\hline 73 & 99 & Bobrow et al., 2016 [96] & Heart diseases & Treatment adherence \\
\hline 74 & 98 & Ly et al., 2014 [97] & Mental health disorders & Self-monitoring \\
\hline 75 & 98 & Worringham et al., 2011 [98] & Heart diseases & Disease controls \\
\hline 76 & 97 & Lim et al., 2012 [99] & Gynecology/obstetrics & Knowledge improvement \\
\hline 77 & 97 & Vilella et al., 2004 [100] & Liver diseases & Vaccination reminders \\
\hline 78 & 97 & Smith et al., 2014 [101] & Obesity & Impact on lifestyle \\
\hline 79 & 97 & Logan et al., 2012 [102] & Heart diseases & Disease controls \\
\hline 80 & 96 & Maddison et al., 2015 [103] & Heart diseases & Impact on lifestyle \\
\hline 81 & 96 & Woolford et al., 2010 [104] & Obesity & Impact on lifestyle \\
\hline 82 & 95 & Buller et al., 2014 [105] & Addiction & Cigarette smoking quitting \\
\hline 83 & 94 & Shapiro et al., 2012 [106] & Obesity & Impact on lifestyle \\
\hline 84 & 93 & Whittaker et al., 2011 [107] & Addiction & Cigarette smoking quitting \\
\hline 85 & 93 & Hebden et al., 2014 [108] & Obesity & Impact on lifestyle \\
\hline 86 & 93 & Aroran et al., 2014 [109] & Diabetes & Disease controls \\
\hline 87 & 93 & Evans et al., 2012 [110] & Gynecology/obstetrics & Knowledge improvement \\
\hline 88 & 92 & Bauer et al., 2003 [111] & Mental health disorders & Diseases control \\
\hline 89 & 92 & Castaño et al., 2012 [112] & Gynecology/obstetrics & Treatment adherence \\
\hline 90 & 91 & Menon-Johansson et al., 2006 [113] & Gynecology/obstetrics & Disease controls \\
\hline 91 & 91 & Abroms et al., 2014 [114] & Addiction & Cigarette smoking quitting \\
\hline 92 & 89 & Holmen et al., 2014 [115] & Diabetes & Self-monitoring \\
\hline 93 & 89 & Bereznak et al., 2012 [116] & Mental health disorders & Self-monitoring \\
\hline 94 & 88 & Aguilera et al., 2011 [117] & Mental health disorders & Disease controls \\
\hline 95 & 88 & Weitzel et al., 2007 [118] & Addiction & Treatment adherence \\
\hline 96 & 88 & Da Costa et al., 2010 [119] & General medicine & Attendance/ appointment reminders \\
\hline 97 & 87 & Naughton et al., 2012 [120] & Addiction & Cigarette smoking quitting \\
\hline 98 & 84 & Haug et al., 2009 [121] & Addiction & Cigarette smoking quitting \\
\hline 99 & 84 & Newton et al., 2009 [122] & Diabetes & Impact on lifestyle \\
\hline 100 & 84 & Geraghty et al., $2008[\underline{123}]$ & ENT diseases & Attendance/ appointment reminders \\
\hline
\end{tabular}

Table 3: Name of journals that published 100 highly cited interventional studies on mobile health

\begin{tabular}{|c|c|c|}
\hline Journal Name & Number & Impact Factor \\
\hline Journal of Medical Internet Research & 9 & 4.945 \\
\hline Lancet & 3 & 59.102 \\
\hline Diabetes Care & 3 & 15.27 \\
\hline Journal of the American Medical Association (JAMA) & 3 & 51.273 \\
\hline PloS One & 3 & 2.776 \\
\hline International Journal of Medical Informatics & 3 & 2.731 \\
\hline Journal of Telemedicine and Telecare & 3 & 2.229 \\
\hline JAMA Internal Medicine/ Archives of Internal Medicine* & 3 & 20.768 \\
\hline Journal of American College Health & 2 & 1.455 \\
\hline Schizophrenia Bulletin & 2 & 7.289 \\
\hline BMC Psychiatry & 2 & 2.666 \\
\hline Pediatrics & 2 & 5.401 \\
\hline Obstetrics and Gynecology & 2 & 4.965 \\
\hline Preventive Medicine & 2 & 3.449 \\
\hline Nicotine \& Tobacco Research & 2 & 3.786 \\
\hline Telemedicine and E-Health & 2 & 1.996 \\
\hline JAMA Dermatology/ Archives of Dermatology** & 2 & 7.995 \\
\hline British Journal of General Practice & 1 & 4.434 \\
\hline AIDS & 1 & 4.499 \\
\hline British Journal of Health Psychology & 1 & 2.472 \\
\hline Tobacco Control & 1 & 6.221 \\
\hline Diabetic Medicine & 1 & 3.107 \\
\hline JAMA Psychiatry & 1 & 15.916 \\
\hline Science Translational Medicine & 1 & 17.2 \\
\hline Family Practice & 1 & 1.986 \\
\hline Obesity & 1 & 3.969 \\
\hline Respiratory Medicine & 1 & 3.237 \\
\hline Diabetes Technology \& Therapeutics & 1 & 4.488 \\
\hline Public Health Nutrition & 1 & 2.526 \\
\hline Lab On A Chip & 1 & 6.914 \\
\hline HEART & 1 & 5.082 \\
\hline Medical Journal of Australia & 1 & 5.438 \\
\hline Journal of Zhejiang University-Science B & 1 & 5.438 \\
\hline
\end{tabular}




\begin{tabular}{|l|c|c|}
\hline Journal Name & Number & Impact Factor \\
\hline JMIR Mhealth And Uhealth & 1 & 4.301 \\
\hline Addiction & 1 & 6.851 \\
\hline Heart Rhythm & 1 & 5.225 \\
\hline Vaccine & 1 & 3.269 \\
\hline Journal of Nutrition Education and Behavior & 1 & 2.869 \\
\hline Health Informatics Journal & 1 & 2.297 \\
\hline Alcoholism-Clinical and Experimental Research & 1 & 3.235 \\
\hline AIDS Patient Care and STDS & 1 & 3.742 \\
\hline Annals of Internal Medicine & 1 & 19.315 \\
\hline Annals of Emergency Medicine & 1 & 5.209 \\
\hline Circulation & 1 & 23.054 \\
\hline Drug and alcohol dependence & 1 & 3.466 \\
\hline BMC ophthalmology & 1 & 1.431 \\
\hline Parkinsonism \& related disorders & 1 & 4.360 \\
\hline JAMA pediatrics & 1 & 12.004 \\
\hline American journal of public health & 1 & 3.243 \\
\hline Behavior therapy & 1 & 5.381 \\
\hline Clinical Infectious Diseases & 1 & 9.055 \\
\hline BMJ-British Medical Journal & 1 & 27.604 \\
\hline Bipolar disorders & 1 & 4.936 \\
\hline Journal of Epidemiology Community Health & 1 & 3.872 \\
\hline European Journal of preventive cardiology & 1 & 5.640 \\
\hline European Eating Disorders Review & 1 & 3.154 \\
\hline Computer methods and programs in biomedicine & 1 & 3.424 \\
\hline Journal of Human Nutrition and Dietetics & 1 & 3.088 \\
\hline Sexually Transmitted Infections & 1 & 3.365 \\
\hline Hypertension & 1 & 7.017 \\
\hline Professional Psychology: Research and Practice & 1 & 1.324 \\
\hline BMC pregnancy and childbirth & 1 & 2.413 \\
\hline Journal of Studies on Alcohol and drugs & 1 & 2.584 \\
\hline American Journal of preventive medicine & 1 & 4.435 \\
\hline BMJ open & 1 & 2.376 \\
\hline BMC public health & 1 & 2.567 \\
\hline Journal of Developmental and Physical Disabilities & 1 & 0.954 \\
\hline Journal Of Nervous and Mental Disease & 1 & 1.859 \\
\hline The Journal of Laryngology \& Otology & 100 & 1.261 \\
\hline Total & & \\
\hline f Interna Medicine was renmed to JAMA Inten & & \\
\hline
\end{tabular}

* The journal of Archives of Internal Medicine was renamed to JAMA Internal Medicine in 2012

** The Journal of Archives of Dermatology was renamed to JAMA Dermatology in 2013

Table 4: First author countries of 100 highly cited interventional studies on mobile health

\begin{tabular}{|l|c|}
\hline Country & No. of articles \\
\hline United States & 45 \\
\hline Australia & 13 \\
\hline United Kingdom & 11 \\
\hline New Zealand & 6 \\
\hline Germany & 3 \\
\hline Spain & 3 \\
\hline Malaysia & 1 \\
\hline Denmark & 2 \\
\hline Canada & 2 \\
\hline Kenya & 2 \\
\hline France & 2 \\
\hline Brazil & 2 \\
\hline Finland & 1 \\
\hline China & 1 \\
\hline Netherlands & 1 \\
\hline Scotland & 1 \\
\hline Sweden & 1 \\
\hline Ireland & 1 \\
\hline Norway & 1 \\
\hline South Africa & 1 \\
\hline Total & 100 \\
\hline
\end{tabular}




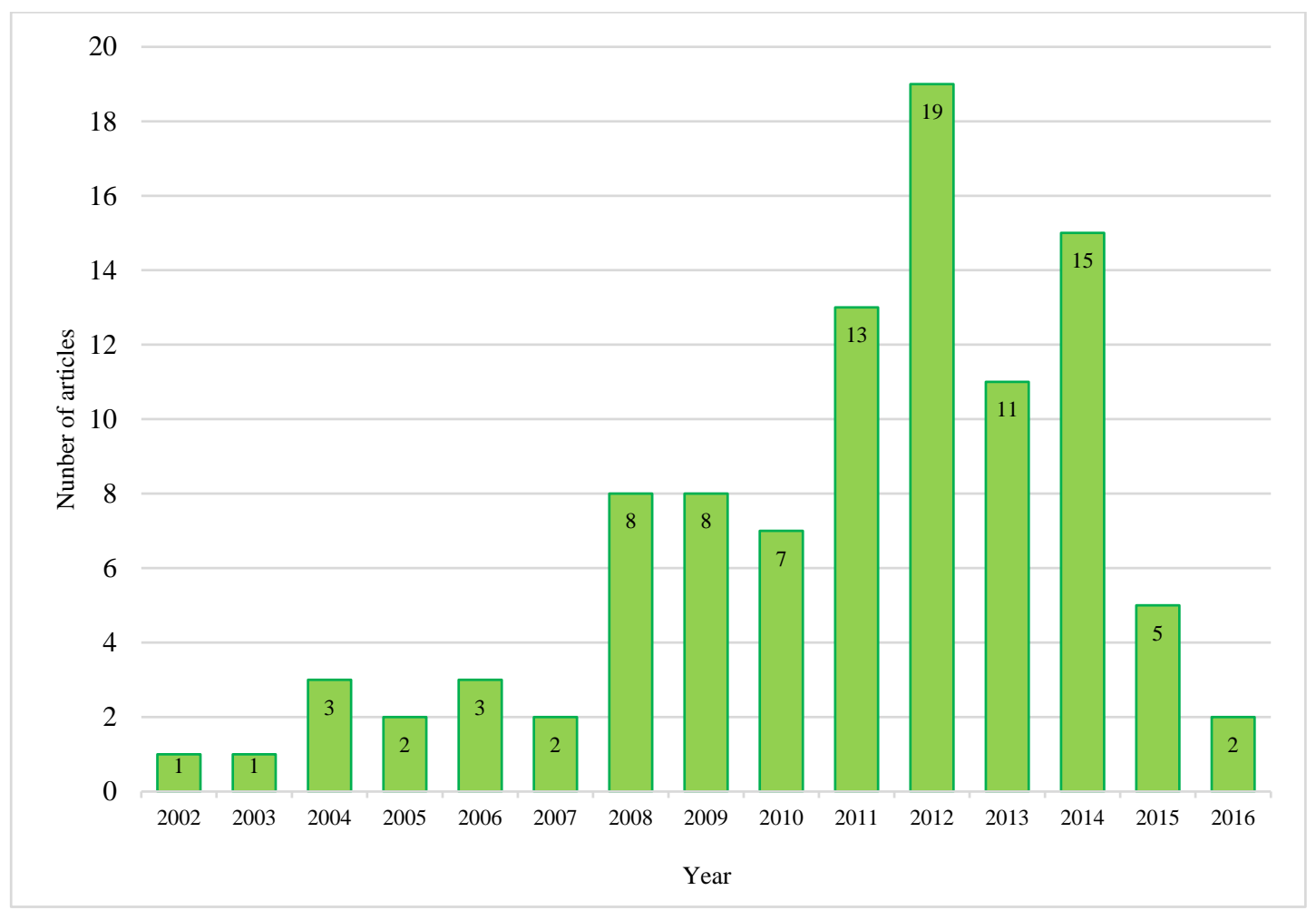

Fig 1: Distribution of 100 highly cited interventional studies on mobile health, based on publication year

\section{DISCUSSION}

This bibliometric study investigated the most cited articles on mobile health intervention. The majority of articles were published in the Journal of Medical Internet Research. Most articles were published in 2012. The highest impact factor among the journals under study was 59.102. The first authors of the majority of studies were from the United States.

From the 100 reviewed articles, most of the interventional studies in the field of mobile health focused on obesity $(n=18)$, addiction $(n=15)$, diabetes $(n=13)$ and mental health disorders $(n=12)$. Eighteen studies that investigated obesity used text messaging services $(n=9)$, mobile applications $(n=6)$, decisionsupport technologies, distance education and consulting, and wearable technologies $(\mathrm{n}=3)$. Control and experimental groups were used in all of these studies. In the majority of studies that focused on obesity ( $\mathrm{n}=18)$, the use of mobile capabilities and other mobile technologies significantly reduced the participants' weight and corrected unhealthy lifestyle behaviours $[\underline{28}, \underline{30}, \underline{38}, \underline{39}, \underline{49}, \underline{54}, \underline{60}, \underline{64}, \underline{66}, \underline{67}, \underline{75}$, $\underline{77}, \underline{86}, \underline{93}, \underline{101}, \underline{104}, \underline{106}, \underline{108]}$. Obesity has significant prevalence as a result of unhealthy lifestyles and improper eating habits. Obesity has been recognised by the World Health Organization as one of the leading causes of global mortality, as it increases the chance of developing potentially risky chronic diseases, such as diabetes, cancers, and musculoskeletal and cardiovascular diseases [124]. ICT-based weight management interventions provide the opportunity to engage a broad audience in a more flexible and cost-effective manner. Mobile telephones may be an interesting visual intervention method because of their popularity and availability at any time and location $[\underline{30}, \underline{125}]$. As the present study has shown, numerous studies have focused on the use of technology in losing weight.

The present study included 15 highly cited papers that discussed using mobile technology interventions for people with substance abuse issues, such as alcoholism $(\mathrm{n}=3)$ and chain-smoking $(\mathrm{n}=12)[\underline{26}, \underline{27}$, $\underline{31}, \underline{42}, \underline{53}, \underline{59}, \underline{71}, \underline{87}, \underline{90}, \underline{105}, \underline{107}, \underline{114}, \underline{118}, \underline{120}$, 121]. Nine text messages and six mobile telephonebased applications were used in these studies. In most studies, the use of text messaging services led to a decrease in drug use for either smoking or alcohol consumption $[\underline{26}, \underline{42}, \underline{53}, \underline{71}, \underline{87}, \underline{105}, \underline{114}, \underline{118}, \underline{120}$, 121]. Overall, in these studies, according to Statista's report [126], informing individuals about the risks of tobacco use, increasing prices, applying certain policies, and implementing purposeful activities can all significantly minimise substance abuse. The text messaging feature of smart telephones can be easily used at any time and place, is cost-effective and is scalable to large crowds, regardless of the individual's location. Moreover, the ability to personalise messages with key user features (such as age, gender and ethnicity) can help control or stop smoking [127]. Studies have shown that sending 
time-sensitive messages with content that may prevent the user from reusing tobacco is another mobile telephone solution for smokers $[\underline{26}, \underline{42}, \underline{53}, \underline{71}$, 87, 105, 114, 118, 120, 121].

It should be noted that, while a limited number of studies have focused on the role of text messages in helping individuals quit smoking, the use of mobile applications and multimedia messages has not effectively ceased this type of substance abuse [ $\underline{53}$, $107,114]$. This may be due to the unwillingness of users to install and employ mobile-based applications. Moreover, in one study, Whittaker et al. [107] found that they could not assess the effect of this technology through a limited random selection of smokers aged 16 and 24 years because, despite the participants' interest in quitting smoking, younger people do not accept interventions for quitting. However, their study was published in 2011, so it is possible that society's perspective has changed over time regarding the risks of drugs, and future studies could examine the effect of mobile application interventions on reducing and ceasing the use of tobacco or other addictive substances. As reported by Statista, the prevalence of smoking among individuals aged 15 to 24 had decreased to $19.1 \%$ in 2000 and will decrease to $12.3 \%$ by 2025 [128].

Based on the results of the present study, the third category of highly cited interventional studies was undertaken in the field of diabetes $(n=13)$. These studies applied text messaging services $(n=6)$, mobile applications $(n=4)$, distance education and remote monitoring systems $(n=3)$ for disease control, selfmonitoring, adherence to treatment and increasing physical activity $[\underline{29}, \underline{32}, \underline{45}, \underline{58}, \underline{65}, \underline{68}, \underline{85}, \underline{89}, \underline{91}, \underline{94}$, $109,115,122]$. In most studies, the use of the potential of mobile telephones and their technologies reduced blood glucose levels, metabolic control, drug administration and adherence to recommended treatments among diabetic patients $[\underline{29}, \underline{32}, \underline{45} \underline{58}$, $\underline{65}, \underline{68}, \underline{85}, \underline{89}, \underline{91}, \underline{115}, \underline{122}]$. In recent years, diabetes has become one of the leading causes of mortality worldwide. According to the World Health Organization, approximately 1.6 million people died of diabetes in 2016, and it is estimated that 425 million people live with diabetes across the world [129]. Moreover, this number is predicted to increase to about 629 million worldwide by 2045 [129]. Modifying lifestyle, increasing physical activity, following a healthy diet and avoiding drug abuse can reduce the risk of diabetes. In addition, early diagnosis of the disease can prevent its later consequences $[\underline{130}, \underline{131}]$. The prevalence of smartphones and mobile technologies around the world may be an effective means for preventing and controlling diabetes, as the studies reviewed in this article indicated this approach to be effective.

Among the 100 highly cited studies examining the effect of mobile technology and its capabilities for mental illnesses, 12 studies were investigated $[\underline{33}, \underline{40}$, $\underline{47}, \underline{48}, \underline{53}, \underline{76}, \underline{79}, \underline{82}, \underline{97}, \underline{111}, \underline{116}, \underline{117}$. The majority of the studies used mobile apps $(n=8)$, while the remainder used text messaging systems $(n=4)$. In these studies, the use of mobile telephone capabilities improved disease control, health-related symptoms and self-monitoring among patients $[\underline{33}, \underline{40}, \underline{47} \underline{48}$, $\underline{53}, \underline{76}, \underline{79}, \underline{82}, \underline{97}, \underline{11}, \underline{116}, 117]$. At present, mental health disorders are increasing worldwide, with 284 million people suffering from anxiety [132]. The psychological disorders studied in the highly cited studies included depression, anxiety, bipolar and borderline disorders, schizophrenia, binge eating disorder and autism. However, despite the significance of mental health disorders and their wide range, limited studies have been conducted in this area. Thus, future studies could investigate the potential of mobile telephones and their technologies for controlling and treating all mental health disorders.

Eight of these studies investigated the potential of mobile telephones for addressing viral diseases, especially human immunodeficiency virus (HIV). In most related studies, text messaging services $(n=6)$ were used to encourage adherence to antiviral treatment among HIV patients $[\underline{24}, \underline{25}, \underline{69}, \underline{70}, \underline{74}, \underline{80}]$. In addition to the effect of text messaging, the use of mobile apps in one study also improved adherence to treatment among these patients [83]. Only one of the studies examined the effect of contextual reminders for vaccination for human papillomavirus [63]. In 2018, almost 37.9 million people were living with HIV in Iran. Among these people, 36.2 million were adults and 1.7 million were children (younger than 15 years) [133]. Meanwhile, human papillomavirus is the leading cause of cervical cancer-the fourth most common cancer among women. According to the World Health Organization, in 2012, this virus had killed 226,000 people around the world [134]. In addition, according to the statistics published by the World Health Organization, $85 \%$ of the global cases of the virus have occurred in less developed countries [134]. Therefore, considering the importance of these viruses in risking the health of people, as well as their potential for transmission, it is important to use all available interventions for the follow-up and control of these diseases. Future studies could investigate the effect of mobile interventions on the follow-up, control and treatment of these diseases and other risky viral diseases.

The other highly cited papers respectively investigated the effect of the potentials of mobile telephones and other mobile technology interventions on cardiovascular disease, pregnancy and postpartum care, sexual health knowledge promotion, melanoma and ovarian cancer diagnosis, malaria control, Parkinson's disease control, hepatitis control, postoperative care of liver transplantation, eye and ear diseases, pharynx and 
nose diseases, and sun care $[\underline{34}-\underline{37}, \underline{41}, \underline{43}, \underline{44}, \underline{46}, \underline{50}$ $\underline{52}, \underline{56}, \underline{57}, \underline{61}, \underline{62}, \underline{72}, \underline{73}, \underline{78}, \underline{81}, \underline{84}, \underline{88}, \underline{92}, \underline{95}, \underline{96}, \underline{98}-$ $\underline{100}, 102,103,110,112,113,119,123]$. The variety of health care domains investigated in these studies reflects the changes in mobile health care research trajectories over the past 20 years. The majority of studies employed the most affordable and accessible mobile text messaging services to control diseases and encourage adherence to disease treatments.

This study had four limitations. The first limitation was that the self-citations and citations given in books and other texts were not investigated. This is based on the policies of calculating the number of citations in the WOS database [7]. The second limitation was that the list of highly cited papers is not fixed and changes over time. Our search strategy was run in August 2020, and the number of citations and article order may change after a period of time. Third, our literature search was restricted to the English language. Articles published in languages other than English may have received unfair citation counts because of bias and poor recognition in the field. Fourth, this study only examined the mobile technology interventions that published in WOS. Maybe most of widely used mobile technologies are not necessarily mentioned in scientific papers in WOS, but are using in public and maybe some of them are just designed as a marketing project. Therefore, future studies can pay attention to this issue.

Numerous studies have investigated highly cited studies in the fields of medical informatics [11], telemedicine [12] and mobile health [19]. In this study, highly cited articles were selected, and the number of citations, number of authors, impact factor of journals, organisational affiliation and country of each article were reviewed. Moreover, this study focused on mobile health and only examined the bibliometric features of all highly cited papers published in this field over a 10-year period (2006 to 2016) [19]. However, the present study was able to classify highly cited interventional mobile health studies. In our study, the most cited article focused on treatment adherence among HIV patients.

\section{CONCLUSION}

Among the 100 reviewed articles, the majority of the interventional mobile health studies focused on obesity, addiction and diabetes. The increased number of citations for articles investigating obesity, addiction and diabetes shows the rising prevalence of these problems in contemporary societies. This also indicates the importance of these diseases and their aftermath. As a result, several studies have examined the effect of mobile technologies on weight loss, physical activity, drug use control and blood glucose control. Based on the results of the present study, there was only one highly cited article about each of the following areas: cancer; neurological diseases; and eye, ear, throat and nose problems. The interventions used in most of the studies were text messages through text messaging services. Few studies have examined the effects of mobile applications and other mobile technologies. Future studies can examine the effects of different mobile applications on various diseases' prevention, control and treatment.

\section{ACKNOWLEDGEMENT}

The authors are grateful to the Medical Informatics Research Center of Kerman University of Medical Sciences.

\section{AUTHOR'S CONTRIBUTION}

A. Ameri, F. Salmanizadeh, and K. Bahaadinbeigy were the responsible for the study design, data analysis, interpretation of results, and writing the manuscript.

The authors agree on this final form of the manuscript, and attested that all authors contributed in the final draft of the manuscript.

\section{CONFLICTS OF INTEREST}

The authors declare no conflicts of interest regarding the publication of this study.

\section{FINANCIAL DISCLOSURE}

No financial interests related to the material of this manuscript have been declared.

\section{REFERENCES}

1. Silva BM, Rodrigues JJ, de la Torre Díez I, LópezCoronado M, Saleem K. Mobile-health: A review of current state in 2015. J Biomed Inform. 2015; 56: 26572. PMID: 26071682 DOI: $10.1016 /$ j.jbi.2015.06.003 [PubMed]

2. Varshney U. Mobile health: Four emerging themes of research. Decision Support Systems. 2014; 66: 20-35.

3. Eichelberg M, Aden T, Riesmeier J, Dogac A, Laleci GB. Electronic health record standards-a brief overview.
International Conference on Information and Communications Technology. IEEE; 2006.

4. Statista. Mobile medical apps market size worldwide in 2017, and a forecast for 2025 (in billion U.S. dollars) [Internet]. 2019 [cited: 4 Agu 2020]. Available from: https://www.statista.com/statistics/877758/globalmobile-medical-apps-market-size

5. Junglas I, Abraham C, Ives B. Mobile technology at the frontlines of patient care: Understanding fit and human drives in utilization decisions and performance. Decision Support Systems. 2009; 46(3): 634-47. 
6. Bui-Mansfield LT. Whatever happened to the 50 most frequently cited articles published in AJR? AJR Am J Roentgenol. 2005; 185(3): 597-601. PMID: 16120905 DOI: 10.2214/ajr.185.3.01850597 [PubMed]

7. Clarivate Web of Science Core Collection. The citation report \& the h-index [Internet]. 2019 [cited: 4 Aug 2020]. Available from: https://clarivate.libguides.com/woscc/citationrepor

8. Fardi A, Kodonas K, Gogos C, Economides N. Top-cited articles in endodontic journals. J Endod. 2011; 37(9): 1183-90. PMID: 21846531 DOI: 10.1016/j.joen.2011.05.037 [PubMed]

9. Hirsch JE. An index to quantify an individual's scientific research output. Proc Natl Acad Sci USA. 2005; 102(46): 16569-72. PMID: 16275915 DOI: 10.1073/pnas.0507655102 [PubMed]

10. Goodman WK, Price LH, Rasmussen SA, Mazure C, Fleischmann RL, Hill CL, et al. The Yale-Brown obsessive compulsive scale: I. Development, use, and reliability. Arch Gen Psychiatry. 1989; 46(11): 100611. $\quad 2684084 \quad$ PMID: 10.1001/archpsyc.1989.01810110048007 [PubMed]

11. Nadri H, Rahimi B, Timpka T, Sedghi S. The top 100 articles in the medical informatics: A bibliometric analysis. J Med Syst. 2017; 41(150): 1-12. PMID: 28825158 DOI: $10.1007 /$ s10916-017-0794-4 [PubMed]

12. Askari A, Khodaie M, Bahaadinbeigy K. The 60 most highly cited articles published in the Journal of Telemedicine and Telecare and Telemedicine Journal and E-health. J Telemed Telecare. 2014; 20(1): 35-43. PMID: 24414396 DOI: 10.1177/1357633X13519899 [PubMed]

13. Mazhari S. The 100 top-cited articles published in psychiatric journals. J Psychiatr Pract. 2013; 19(4): 327-38. PMID: 23852109 DOI: 10.1097/01.pra.0000432604.06835.da [PubMed]

14. Ohba N, Nakao K, Isashiki Y, Ohba A. The 100 most frequently cited articles in ophthalmology journals. Arch Ophthalmol. 2007; 125(7): 952-60. PMID: 17620577 DOI: $10.1001 /$ archopht.125.7.952 [PubMed]

15. Ponce FA, Lozano AM. Highly cited works in neurosurgery. Part I: The 100 top-cited papers in neurosurgical journals. J Neurosurg. 2010; 112(2): 223-32. PMID: 20078192 DOI: 10.3171/2009.12.JNS091599 [PubMed]

16. Hennessey K, Afshar K, MacNeily AE. The top 100 cited articles in urology. Can Urol Assoc J. 2009; 3(4): 293. PMID: 19672442 DOI: 10.5489/cuaj.1123 [PubMed]

17. Rosenberg AL, Tripathi RS, Blum J. The most influential articles in critical care medicine. J Crit Care. 2010; 25(1): 157-70. PMID: 19327953 DOI: 10.1016/j.jcrc.2008.12.010 [PubMed]

18. Tsai YL, Lee CC, Chen SC, Yen ZS. Top-cited articles in emergency medicine. Am J Emerg Med. 2006; 24(6): 647-54. PMID: 16984831 DOI: 10.1016/j.ajem.2006.01.001 [PubMed]
19. Sweileh WM, Al-Jabi SW, AbuTaha AS, Sa'ed HZ, Anayah FM, Sawalha AF. Bibliometric analysis of worldwide scientific literature in mobile-health: 2006-2016. BMC Med Inform Decis Mak. 2017; 17(72): 1-12. PMID: 28558687 DOI: 10.1186/s12911017-0476-7 [PubMed]

20. Dolan RS, Hanna TN, Warraich GJ, Johnson JO, Khosa F. The top 100 articles in the radiology of trauma: A bibliometric analysis. Emerg Radiol. 2015; 22(6): 667-75. PMID: 26377425 DOI: 10.1007/s10140-0151345-2 [PubMed]

21. Moed HF. New developments in the use of citation analysis in research evaluation. Arch Immunol Ther Exp. 2009; 57(13): 1-5. PMID: 19219533 DOI: 10.1007/s00005-009-0001-5 [PubMed]

22. Rolim KM, Pinheiro MC, Pinheiro PR, Frota MA, de Vasconcelos Filho JE, de Sousa Martins I, et al. Mobile Partogram-m-Health technology in the promotion of parturient's health in the delivery room. In: Lytras MD, Sarirete A [eds]. Innov Health Inform. Academic Press; 2020.

23. Clarivate Web of Science Core Collection. Help [Internet]. 2020 [cited: 20 Aug 2020]. Available from: https://images.webofknowledge.com/images/help/ WOS/hs_topic.html

24. Lester RT, Ritvo P, Mills EJ, Kariri A, Karanja S, Chung $\mathrm{MH}$, et al. Effects of a mobile phone short message service on antiretroviral treatment adherence in Kenya (WelTel Kenya1): A randomised trial. Lancet. 2010; 376(9755): 1838-45. PMID: 21071074 DOI: 10.1016/S0140-6736(10)61997-6 [ㅁuMed]

25. Pop-Eleches C, Thirumurthy H, Habyarimana JP, Zivin JG, Goldstein MP, De Walque D, et al. Mobile phone technologies improve adherence to antiretroviral treatment in a resource-limited setting: A randomized controlled trial of text message reminders. AIDS. 2011; 25(6): 825-34. PMID: 21252632 DOI: 10.1097/QAD.0b013e32834380c1 [PubMed]

26. Rodgers A, Corbett T, Bramley D, Riddell T, Wills M, Lin RB, et al. Do u smoke after txt? Results of a randomised trial of smoking cessation using mobile phone text messaging. Tob Control. 2005; 14(4): 25561. PMID: 16046689 DOI: 10.1136/tc.2005.011577 [PubMed]

27. Free C, Knight R, Robertson S, Whittaker R, Edwards $\mathrm{P}$, Zhou W, et al. Smoking cessation support delivered via mobile phone text messaging (txt2stop): A singleblind, randomised trial. Lancet. 2011; 378(9785): 4955. PMID: 21722952 DOI: 10.1016/S01406736(11)60701-0 [PubMed]

28. Patrick K, Raab F, Adams M, Dillon L, Zabinski M, Rock C, et al. A text message-based intervention for weight loss: Randomized controlled trial. J Med Internet Res. 2009; 11(1): 1-9. PMID: 19141433 DOI: 10.2196/jmir.1100 [ubMed]

29. Franklin VL, Waller A, Pagliari C, Greene SA. A randomized controlled trial of Sweet Talk, a textmessaging system to support young people with diabetes. Diabet Med. 2006; 23(12): 1332-8. PMID: 17116184 DOI: 10.1111/j.1464-5491.2006.01989.x [PubMed] 
30. Carter MC, Burley VJ, Nykjaer C, Cade JE. Adherence to a smartphone application for weight loss compared to website and paper diary: Pilot randomized controlled trial. J Med Internet Res. 2013; 15(4): 1-17. PMID: 23587561 DOI: 10.2196/jmir.2283 [ㅁubMed]

31. Gustafson DH, McTavish FM, Chih MY, Atwood AK, Johnson RA, Boyle MG, et al. A smartphone application to support recovery from alcoholism: A randomized clinical trial. JAMA Psychiatry. 2014; 71(5): 566-72. PMID: $24671165 \quad$ DOI: 10.1001/jamapsychiatry.2013.4642 [ubMed]

32. Quinn CC, Shardell MD, Terrin ML, Barr EA, Ballew SH, Gruber-Baldini AL. Cluster-randomized trial of a mobile phone personalized behavioral intervention for blood glucose control. Diabetes Care. 2011; 34(9): 1934-42. PMID: 21788632 DOI: 10.2337/dc11-0366 [PubMed]

33. Burns MN, Begale M, Duffecy J, Gergle D, Karr CJ, Giangrande E, et al. Harnessing context sensing to develop a mobile intervention for depression. J Med Internet Res. 2011; 13(3): 1-17. PMID: 21840837 DOI: 10.2196/jmir.1838 [PubMed]

34. Chow CK, Redfern J, Hillis GS, Thakkar J, Santo K, Hackett ML, et al. Effect of lifestyle-focused text messaging on risk factor modification in patients with coronary heart disease: A randomized clinical trial. J Am Med Assoc. 2015; 314(12): 1255-63. PMID: 26393848 DOI: 10.1001/jama.2015.10945 [PubMed]

35. Zurovac D, Sudoi RK, Akhwale WS, Ndiritu M, Hamer $\mathrm{DH}$, Rowe AK, et al. The effect of mobile phone textmessage reminders on Kenyan health workers' adherence to malaria treatment guidelines: A cluster randomised trial. Lancet. 2011; 378(9793): 795-803. PMID: 21820166 DOI: $10.1016 / S 0140-$ 6736(11)60783-6 [ㄹued]

36. Laksanasopin T, Guo TW, Nayak S, Sridhara AA, Xie S, Olowookere 00, et al. A smartphone dongle for diagnosis of infectious diseases at the point of care. Sci Transl Med. 2015; 7(273): 1-11. PMID: 25653222 DOI: 10.1126/scitranslmed.aaa0056 [PubMed]

37. Stockwell MS, Kharbanda EO, Martinez RA, Vargas CY, Vawdrey DK, Camargo S. Effect of a text messaging intervention on influenza vaccination in an urban, low-income pediatric and adolescent population: A randomized controlled trial. J Am Med Assoc. 2012; 307(16): 1702-8. PMID: 22535855 DOI: 10.1001/jama.2012.502 [PubMed]

38. Napolitano MA, Hayes S, Bennett GG, Ives AK, Foster GD. Using Facebook and text messaging to deliver a weight loss program to college students. Obesity. 2013; 21(1): 25-31. PMID: 23505165 DOI: 10.1002/oby.20232 [PubMed]

39. Jakicic JM, Davis KK, Rogers RJ, King WC, Marcus MD, Helsel D, et al. Effect of wearable technology combined with a lifestyle intervention on long-term weight loss: The IDEA randomized clinical trial. JAMA. 2016; 316(11): 1161-71. PMID: 27654602 DOI: 10.1001/jama.2016.12858 [PubMed]

40. Ben-Zeev D, Brenner CJ, Begale M, Duffecy J, Mohr DC, Mueser KT. Feasibility, acceptability, and preliminary efficacy of a smartphone intervention for schizophrenia. Schizophr Bull. 2014; 40(6): 1244-53. PMID: 24609454 DOI: 10.1093/schbul/sbu033 [PubMed]

41. Wolf JA, Moreau JF, Akilov O, Patton T, English JC, Ho J, et al. Diagnostic inaccuracy of smartphone applications for melanoma detection. JAMA Dermatol. 2013; 149(4): 422-6. PMID: 23325302 DOI: 10.1001/jamadermatol.2013.2382 [PubMed]

42. Obermayer JL, Riley WT, Asif 0, Jean-Mary J. College smoking-cessation using cell phone text messaging. J Am Coll Health. 2004; 53(2): 71-8. PMID: 15495883 DOI: 10.3200/JACH.53.2.71-78 [PubMed]

43. Strandbygaard U, Thomsen SF, Backer V. A daily SMS reminder increases adherence to asthma treatment: a three-month follow-up study. Respir Med. 2010; 104(2): 166-71. PMID: 19854632 DOI: 10.1016/j.rmed.2009.10.003 [PubMed]

44. Leong KC, Chen WS, Leong KW, Mastura I, Mimi O, Sheikh MA, et al. The use of text messaging to improve attendance in primary care: A randomized controlled trial. Fam Pract. 2006; 23(6): 699-705. PMID: 16916871 DOI: 10.1093/fampra/cml044 [PubMed]

45. Hanauer DA, Wentzell K, Laffel N, Laffel LM. Computerized automated reminder diabetes system (CARDS): E-mail and SMS cell phone text messaging reminders to support diabetes management. Diabetes Technol Ther. 2009; 11(2): 99-106. PMID: 19848576 DOI: 10.1089/dia.2008.0022 [PubMed]

46. Varnfield M, Karunanithi M, Lee CK, Honeyman E, Arnold D, Ding H, et al. Smartphone-based home care model improved use of cardiac rehabilitation in postmyocardial infarction patients: Results from a randomised controlled trial. Heart. 2014; 100(22): 1770-9. PMID: 24973083 DOI: 10.1136/heartjnl2014-305783 [PubMed]

47. Granholm E, Ben-Zeev D, Link PC, Bradshaw KR, Holden JL. Mobile Assessment and Treatment for Schizophrenia (MATS): A pilot trial of an interactive text-messaging intervention for medication adherence, socialization, and auditory hallucinations. Schizophr Bull. 2012; 38(3): 414-25. PMID: 22080492 DOI: $10.1093 /$ schbul/sbr155 [PubMed]

48. Depp CA, Mausbach B, Granholm E, Cardenas V, BenZeev D, Patterson TL, et al. Mobile interventions for severe mental illness: Design and preliminary data from three approaches. J Nerv Ment Dis. 2010; 198(10): 715-21. PMID: 20921861 DOI: 10.1097/NMD.0b013e3181f49ea3 [PubMed]

49. Haapala I, Barengo NC, Biggs S, Surakka L, Manninen P. Weight loss by mobile phone: A 1-year effectiveness study. Public Health Nutr. 2009; 12(12): 2382-91. PMID: $19323865 \quad$ DOI: $10.1017 / \mathrm{S} 1368980009005230$ [PubMed]

50. Armstrong AW, Watson AJ, Makredes M, Frangos JE, Kimball AB, Kvedar JC. Text-message reminders to improve sunscreen use: A randomized, controlled trial using electronic monitoring. Arch Dermatol. 2009; 145(11): 1230-6. PMID: 19917951 DOI: 10.1001/archdermatol.2009.269 [ubMed]

51. Petrie KJ, Perry K, Broadbent E, Weinman J. A text 
message programme designed to modify patients' illness and treatment beliefs improves self-reported adherence to asthma preventer medication. $\mathrm{Br} \mathrm{J}$ Health Psychol. 2012; 17(1): 74-84. PMID: 22107110 DOI: 10.1111/j.2044-8287.2011.02033.x [PubMed]

52. Wang S, Zhao X, Khimji I, Akbas R, Qiu W, Edwards D, et al. Integration of cell phone imaging with microchip ELISA to detect ovarian cancer HE4 biomarker in urine at the point-of-care. Lab Chip. 2011; 11(20): 3411-8. PMID: 21881677 DOI: 10.1039/c1lc20479c [PubMed]

53. Borland R, Balmford J, Benda P. Population-level effects of automated smoking cessation help programs: A randomized controlled trial. Addiction. 2013; 108(3): 618-28. PMID: 22994457 DOI: 10.1111/j.1360-0443.2012.04091.x [PubMed]

54. King AC, Hekler EB, Grieco LA, Winter SJ, Sheats JL, Buman MP, et al. Harnessing different motivational frames via mobile phones to promote daily physical activity and reduce sedentary behavior in aging adults. PLoS One. 2013; 8(4): 1-8. PMID: 23638127 DOI: 10.1371/journal.pone.0062613 [PubMed]

55. Watts S, Mackenzie A, Thomas C, Griskaitis A, Mewton L, Williams A, et al. CBT for depression: a pilot RCT comparing mobile phone vs. computer. BMC Psychiatry. 2013; 13(1): 49. PMID: 23391304 DOI: 10.1186/1471-244X-13-49 [PubMed]

56. Downer SR, Meara JG, Da Costa AC. Use of SMS text messaging to improve outpatient attendance. Med J Aust. 2005; 183(7): 366-8. PMID: 16201955 DOI: 10.5694/j.1326-5377.2005.tb07085.x [ubMed]

57. Chen ZW, Fang LZ, Chen LY, Dai HL. Comparison of an SMS text messaging and phone reminder to improve attendance at a health promotion center: A randomized controlled trial. J Zhejiang Univ Sci B. 2008; 9(1): 34-8. PMID: 18196610 DOI: 10.1631/jzus.B071464 [PubMed]

58. Kirwan M, Vandelanotte C, Fenning A, Duncan MJ. Diabetes self-management smartphone application for adults with type 1 diabetes: Randomized controlled trial. J Med Internet Res. 2013; 15(11): 114. PMID: 24225149 DOI: $10.2196 /$ jmir.2588 [PubMed]

59. Bricker JB, Mull KE, Kientz JA, Vilardaga R, Mercer LD, Akioka KJ, et al. Randomized, controlled pilot trial of a smartphone app for smoking cessation using acceptance and commitment therapy. Drug Alcohol Depend. 2014; 143: 87-94. PMID: 25085225 DOI: 10.1016/j.drugalcdep.2014.07.006 [PubMed]

60. Laing BY, Mangione CM, Tseng CH, Leng M, Vaisberg E, Mahida $M$, et al. Effectiveness of a smartphone application for weight loss compared with usual care in overweight primary care patients: A randomized, controlled trial. Ann Intern Med. 2014; 161(10 Supp): S5-12. PMID: 25402403 DOI: 10.7326/M13-3005 [PubMed]

61. Miloh T, Annunziato R, Arnon R, Warshaw J, Parkar S, Suchy FJ, et al. Improved adherence and outcomes for pediatric liver transplant recipients by using text messaging. Pediatrics. 2009; 124(5): e844-50. PMID: 19822583 DOI: $10.1542 /$ peds.2009-0415 [PubMed]
62. McManus DD, Lee J, Maitas O, Esa N, Pidikiti R, Carlucci A, et al. A novel application for the detection of an irregular pulse using an iPhone $4 \mathrm{~S}$ in patients with atrial fibrillation. Heart Rhythm. 2013; 10(3): 315-9. PMID: 23220686 DOI: 10.1016/j.hrthm.2012.12.001 [PubMed]

63. Kharbanda EO, Stockwell MS, Fox HW, Andres R, Lara M, Rickert VI. Text message reminders to promote human papillomavirus vaccination. Vaccine. 2011; 29(14): 2537-41. PMID: 21300094 DOI: 10.1016/j.vaccine.2011.01.065 [ [PubMed]

64. Shapiro JR, Bauer S, Hamer RM, Kordy H, Ward D, Bulik CM. Use of text messaging for monitoring sugarsweetened beverages, physical activity, and screen time in children: A pilot study. J Nutr Educ Behav. 2008; 40(6): 385-91. PMID: 18984496 DOI: 10.1016/j.jneb.2007.09.014 [PubMed]

65. Charpentier G, Benhamou PY, Dardari D, Clergeot A, Franc S, Schaepelynck-Belicar P, et al. The Diabeo software enabling individualized insulin dose adjustments combined with telemedicine support improves $\mathrm{HbA} 1 \mathrm{c}$ in poorly controlled type 1 diabetic patients: A 6-month, randomized, open-label, parallelgroup, multicenter trial (TeleDiab 1 Study). Diabetes Care. 2011; 34(3): 533-9. PMID: 21266648 DOI: $10.2337 / \mathrm{dc} 10-1259$ [PubMed]

66. Gerber BS, Stolley MR, Thompson AL, Sharp LK, Fitzgibbon ML. Mobile phone text messaging to promote healthy behaviors and weight loss maintenance: A feasibility study. Health Informatics J. 2009; 15(1): 17-25. PMID: 19218309 DOI: $10.1177 / 1460458208099865$ [PubMed]

67. Spring B, Schneider K, McFadden HG, Vaughn J, Kozak AT, Smith M, et al. Multiple behavior changes in diet and activity: A randomized controlled trial using mobile technology. Arch Intern Med. 2012; 172(10): 789-96. PMID: 22636824 DOI: 10.1001/archinternmed.2012.1044 [PubMed]

68. Vervloet M, van Dijk L, Santen-Reestman J, Van Vlijmen B, Van Wingerden P, Bouvy ML, et al. SMS reminders improve adherence to oral medication in type 2 diabetes patients who are real time electronically monitored. Int J Med Inform. 2012; 81(9): 594-604. PMID: 22652012 DOI: 10.1016/j.ijmedinf.2012.05.005 [PubMed]

69. Mbuagbaw L, Thabane L, Ongolo-Zogo P, Lester RT, Mills EJ, Smieja M, et al. The Cameroon mobile phone SMS (CAMPS) trial: a randomized trial of text messaging versus usual care for adherence to antiretroviral therapy. PloS One. 2012; 7(12): 1-7. PMID: 23236345 DOI: 10.1371/journal.pone.0046909 [PubMed]

70. Hardy H, Kumar V, Doros G, Farmer E, Drainoni ML, Rybin D, et al. Randomized controlled trial of a personalized cellular phone reminder system to enhance adherence to antiretroviral therapy. AIDS Patient Care STDS. 2011; 25(3): 153-61. PMID: 21323532 DOI: 10.1089/apc.2010.0006 [PubMed]

71. Suffoletto B, Callaway C, Kristan J, Kraemer K, Clark DB. Text-message-based drinking assessments and brief interventions for young adults discharged from 
the emergency department. Alcohol Clin Exp Res. 2012; 36(3): 552-60. PMID: 22168137 DOI: 10.1111/j.1530-0277.2011.01646.x [PubMed]

72. Arora S, Venkataraman V, Zhan A, Donohue S, Biglan $\mathrm{KM}$, Dorsey ER, et al. Detecting and monitoring the symptoms of Parkinson's disease using smartphones: A pilot study. Parkinsonism Relat Disord. 2015; 21(6): 650-3. $\quad$ PMID: 25819808 DOI: 10.1016/j.parkreldis.2015.02.026 [PubMed]

73. Koshy E, Car J, Majeed A. Effectiveness of mobilephone short message service (SMS) reminders for ophthalmology outpatient appointments: Observational study. BMC Ophthalmol. 2008; 8(1): 16. PMID: 18513438 DOI: 10.1186/1471-2415-8-9 [PubMed]

74. Dowshen N, Kuhns LM, Johnson A, Holoyda BJ, Garofalo R. Improving adherence to antiretroviral therapy for youth living with HIV/AIDS: A pilot study using personalized, interactive, daily text message reminders. J Med Internet Res. 2012; 14(2): 1-8. PMID: 22481246 DOI: 10.2196/jmir.2015 [PubMed]

75. Haines J, McDonald J, O'Brien A, Sherry B, Bottino CJ, Schmidt ME, et al. Healthy habits, happy homes: Randomized trial to improve household routines for obesity prevention among preschool-aged children. JAMA Pediatr. 2013; 167(11): 1072-9. PMID: 24019074 DOI: 10.1001/jamapediatrics.2013.2356 [PubMed]

76. Rizvi SL, Dimeff LA, Skutch J, Carroll D, Linehan MM. A pilot study of the DBT coach: an interactive mobile phone application for individuals with borderline personality disorder and substance use disorder. Behav Ther. 2011; 42(4): 589-600. PMID: 22035988 DOI: 10.1016/j.beth.2011.01.003 [ubMed]

77. Glynn LG, Hayes PS, Casey M, Glynn F, Alvarez-Iglesias A, Newell J, et al. Effectiveness of a smartphone application to promote physical activity in primary care: The SMART MOVE randomised controlled trial. Br J Gen Pract. 2014; 64(624): e384-91. PMID: 24982490 D0I: 10.3399/bjgp14X680461 [PubMed]

78. Stockwell MS, Kharbanda EO, Martinez RA, Lara M, Vawdrey D, Natarajan K, et al. Text4Health: Impact of text message reminder-recalls for pediatric and adolescent immunizations. Am J Public Health. 2012; 102(2): e15-21. PMID: 22390457 DOI: 10.2105/AJPH.2011.300331 [PubMed]

79. Proudfoot J, Clarke J, Birch MR, Whitton AE, Parker G, Manicavasagar $\mathrm{V}$, et al. Impact of a mobile phone and web program on symptom and functional outcomes for people with mild-to-moderate depression, anxiety and stress: A randomised controlled trial. BMC Psychiatry. 2013; 13(312): 1-12. PMID: 24237617 DOI: 10.1186/1471-244X-13-312 [PubMed]

80. da Costa TM, Barbosa BJ, Gomes e Costa DA, Sigulem D, de Fátima Marin H, Castelo Filho A, et al. Results of a randomized controlled trial to assess the effects of a mobile SMS-based intervention on treatment adherence in HIV/AIDS-infected Brazilian women and impressions and satisfaction with respect to incoming messages. Int J Med Inform. 2012; 81(4): 257-69. PMID:

\subsection{6/j.ijmedinf.2011.10.002 [PubMed]}

81. Hou MY, Hurwitz S, Kavanagh E, Fortin J, Goldberg AB. Using daily text-message reminders to improve adherence with oral contraceptives: A randomized controlled trial. Obstet Gynecol. 2010; 116(3): 63340. PMID: 20733446 DOI: 10.1097/AOG.0b013e3181eb6b0f [PubMed]

82. Bopp JM, Miklowitz DJ, Goodwin GM, Stevens W, Rendell JM, Geddes JR. The longitudinal course of bipolar disorder as revealed through weekly text messaging: A feasibility study. Bipolar Disord. 2010; 12(3): 327-34. PMID: 20565440 DOI: 10.1111/j.1399-5618.2010.00807.x [PubMed]

83. Altice FL, Maru DS, Bruce RD, Springer SA, Friedland GH. Superiority of directly administered antiretroviral therapy over self-administered therapy among HIV-infected drug users: A prospective, randomized, controlled trial. Clin Infect Dis. 2007; 45(6): 770-8. PMID: 17712763 DOI: $10.1086 / 521166$ [PubMed]

84. Ryan D, Price D, Musgrave SD, Malhotra S, Lee AJ, Ayansina D, et al. Clinical and cost effectiveness of mobile phone supported self monitoring of asthma: Multicentre randomised controlled trial. BMJ. 2012; 344(e1756): 1-15. PMID: 22446569 DOI: 10.1136/bmj.e1756 [PubMed]

85. Franklin V, Greene A, Waller A, Greene S, Pagliari C. Patients' engagement with "Sweet Talk"-a text messaging support system for young people with diabetes. J Med Internet Res. 2008; 10(2): 1-11. PMID: 18653444 DOI: $10.2196 / j m i r .962$ [PubMed]

86. Spring B, Duncan JM, Janke EA, Kozak AT, McFadden $\mathrm{HG}$, DeMott $A$, et al. Integrating technology into standard weight loss treatment: A randomized controlled trial. JAMA Intern Med. 2013; 173(2): 10511. PMID: $23229890 \quad$ DOI: 10.1001/jamainternmed.2013.1221 [PubMed]

87. Riley W, Obermayer J, Jean-Mary J. Internet and mobile phone text messaging intervention for college smokers. J Am Coll Health. 2008; 57(2): 245-8. PMID: 18809542 DOI: $\quad 10.3200 / \mathrm{JACH} .57 .2 .245-248$ [PubMed]

88. Kirwan M, Duncan MJ, Vandelanotte C, Mummery WK. Using smartphone technology to monitor physical activity in the 10,000 Steps program: A matched casecontrol trial. J Med Internet Res. 2012; 14(2): 1-10. PMID: 22522112 DOI: 10.2196/jmir.1950 [PubMed]

89. Istepanian RS, Zitouni $\mathrm{K}$, Harry D, Moutosammy $\mathrm{N}$, Sungoor A, Tang B, et al. Evaluation of a mobile phone telemonitoring system for glycaemic control in patients with diabetes. J Telemed Telecare. 2009; 15: 125-8. PMID: 19364893 DOI: 10.1258/jtt.2009.003006 [PubMed]

90. Whittaker R, Maddison R, McRobbie H, Bullen C, Denny S, Dorey E, et al. A multimedia mobile phonebased youth smoking cessation intervention: Findings from content development and piloting studies. J Med Internet Res. 2008; 10(5): 1-13. PMID: 19033148 DOI: 10.2196/jmir.1007 [PubMed]

91. Ferrer-Roca 0, Cardenas A, Diaz-Cardama A, Pulido P. 
Mobile phone text messaging in the management of diabetes. J Telemed Telecare. 2004; 10(5): 282-5. PMID: 15494086 DOI: $10.1258 / 1357633042026341$ [PubMed]

92. Baker DW, Brown T, Buchanan DR, Weil J, Balsley K, Ranalli L, et al. Comparative effectiveness of a multifaceted intervention to improve adherence to annual colorectal cancer screening in community health centers: A randomized clinical trial. JAMA Intern Med. 2014; 174(8): 1235-41. PMID: 24934845 DOI: 10.1001/jamainternmed.2014.2352 [PubMed]

93. Wang JB, Cadmus-Bertram LA, Natarajan L, White MM, Madanat $H$, Nichols JF, et al. Wearable sensor/device (Fitbit One) and SMS text-messaging prompts to increase physical activity in overweight and obese adults: A randomized controlled trial. Telemed J E Health. 2015; 21(10): 782-92. PMID: 26431257 DOI: $10.1089 / \mathrm{tmj} .2014 .0176$ [ubMed]

94. Gómez EJ, Hernando ME, Garcia A, Del Pozo F, Cermeno J, Corcoy RA, et al. Telemedicine as a tool for intensive management of diabetes: The DIABTel experience. Comput Methods Programs Biomed. 2002; 69(2): 163-77. PMID: 12100795 DOI: 10.1016/s0169-2607(02)00039-1 [PubMed]

95. Lund S, Nielsen BB, Hemed M, Boas IM, Said A, Said K, et al. Mobile phones improve antenatal care attendance in Zanzibar: A cluster randomized controlled trial. BMC Pregnancy Childbirth. 2014; 14(29): 1-10. PMID: 24438517 DOI: 10.1186/14712393-14-29 [PubMed]

96. Bobrow K, Farmer AJ, Springer D, Shanyinde M, Yu LM, Brennan $\mathrm{T}$, et al. Mobile phone text messages to support treatment adherence in adults with high blood pressure (SMS-Text Adherence Support [StAR]): A single-blind, randomized trial. Circulation. 2016; 133(6): 592-600. PMID: 26769742 DOI: 10.1161/CIRCULATIONAHA.115.017530 [PubMed]

97. Ly KH, Trüschel A, Jarl L, Magnusson S, Windahl T, Johansson R, Carlbring P, et al. Behavioural activation versus mindfulness-based guided self-help treatment administered through a smartphone application: A randomised controlled trial. BMJ Open. 2014; 4(1): e003440. PMID: 24413342 DOI: 10.1136/bmjopen2013-003440 [PubMed]

98. Worringham C, Rojek A, Stewart I. Development and feasibility of a smartphone, ECG and GPS based system for remotely monitoring exercise in cardiac rehabilitation. PloS One. 2011; 6(2): 1-6. PMID: 21347403 DOI: 10.1371 /journal.pone.0014669 [PubMed]

99. Lim MS, Hocking JS, Aitken CK, Fairley CK, Jordan L, Lewis JA, et al. Impact of text and email messaging on the sexual health of young people: A randomised controlled trial. J Epidemiol Community Health. 2012; 66(1): 69-74. PMID: 21415232 DOI: 10.1136/jech.2009.100396 [PubMed]

100. Vilella A, Bayas JM, Diaz MT, Guinovart C, Diez C, Simó $\mathrm{D}$, et al. The role of mobile phones in improving vaccination rates in travelers. Prev Med. 2004; 38(4): 503-9. PMID: $15020186 \quad$ DOI: 10.1016/j.ypmed.2003.12.005 [PubMed]
101. Smith JJ, Morgan PJ, Plotnikoff RC, Dally KA, Salmon J, Okely AD, et al. Smart-phone obesity prevention trial for adolescent boys in low-income communities: The ATLAS RCT. Pediatrics. 2014; 134(3): e723-31. PMID: 25157000 DOI: 10.1542/peds.2014-1012 [PubMed]

102. Logan AG, Irvine MJ, McIsaac WJ, Tisler A, Rossos PG, Easty A, et al. Effect of home blood pressure telemonitoring with self-care support on uncontrolled systolic hypertension in diabetics. Hypertens. 2012; 60(1): 51-7. PMID: 22615116 DOI: 10.1161/HYPERTENSIONAHA.111.188409 [PubMed]

103. Maddison R, Pfaeffli L, Whittaker R, Stewart R, Kerr A, Jiang $Y$, et al. A mobile phone intervention increases physical activity in people with cardiovascular disease: Results from the HEART randomized controlled trial. Eur J Prev Cardiol. 2015; 22(6): 7019. PMID: $24817694 \quad$ DOI: $10.1177 / 2047487314535076$ [PubMed]

104. Woolford SJ, Clark SJ, Strecher VJ, Resnicow K. Tailored mobile phone text messages as an adjunct to obesity treatment for adolescents. J Telemed Telecare. 2010; 16(8): 458-61. PMID: 20959393 DOI: 10.1258/jtt.2010.100207 [PubMed]

105. Buller DB, Borland R, Bettinghaus EP, Shane JH, Zimmerman DE. Randomized trial of a smartphone mobile application compared to text messaging to support smoking cessation. Telemed J E Health. 2014; 20(3): 206-14. PMID: 24350804 DOI: 10.1089/tmj.2013.0169 [PubMed]

106. Shapiro JR, Koro T, Doran N, Thompson S, Sallis JF, Calfas K, et al. Text4Diet: A randomized controlled study using text messaging for weight loss behaviors. Prev Med. 2012; 55(5): 412-7. PMID: 22944150 DOI: 10.1016/j.ypmed.2012.08.011 [PubMed]

107. Whittaker R, Dorey E, Bramley D, Bullen C, Denny S, Elley CR, et al. A theory-based video messaging mobile phone intervention for smoking cessation: Randomized controlled trial. J Med Internet Res. 2011; 13(1): 1-12. PMID: 21371991 DOI: 10.2196/jmir.1553 [PubMed]

108. Hebden L, Cook A, Van Der Ploeg HP, King L, Bauman A, Allman-Farinelli M. A mobile health intervention for weight management among young adults: A pilot randomised controlled trial. J Hum Nutr Diet. 2014; 27(4): 322-32. PMID: 23992038 DOI: 10.1111/jhn.12155 [PubMed]

109. Arora S, Peters AL, Burner E, Lam CN, Menchine M. Trial to examine text message-based mHealth in emergency department patients with diabetes (TExTMED): A randomized controlled trial. Ann Emerg Med. 2014; 63(6): 745-54. PMID: 24225332 DOI: 10.1016/j.annemergmed.2013.10.012 [마Med]

110. Evans WD, Wallace JL, Snider J. Pilot evaluation of the text4baby mobile health program. BMC Public Health. 2012; 12: 1031. PMID: 23181985 DOI: 10.1186/1471-2458-12-1031 [PubMed]

111. Bauer S, Percevic R, Okon E, Meermann RU, Kordy H. Use of text messaging in the aftercare of patients with bulimia nervosa. Europian Eating Disorders Review. 2003; 11(3): 279-90. 
112. Castaño PM, Bynum JY, Andrés R, Lara M, Westhoff C. Effect of daily text messages on oral contraceptive continuation: A randomized controlled trial. Obstet Gynecol. 2012; 119(1): 14-20. PMID: 22143257 DOI: 10.1097/AOG.0b013e31823d4167 [ubMed]

113. Menon-Johansson AS, McNaught F, Mandalia S, Sullivan AK. Texting decreases the time to treatment for genital Chlamydia trachomatis infection. Sex Transm Infect. 2006; 82(1): 49-51. PMID: 16461603 DOI: $10.1136 /$ sti.2004.014381 [PubMed]

114. Abroms LC, Boal AL, Simmens SJ, Mendel JA, Windsor RA. A randomized trial of Text2Quit: A text messaging program for smoking cessation. Am J Prev Med. 2014; 47(3): 242-50. PMID: 24913220 DOI: 10.1016/j.amepre.2014.04.010 [ [PubMed]

115. Holmen $\mathrm{H}$, Torbjørnsen A, Wahl AK, Jenum AK, Småstuen MC, Årsand E, et al. A mobile health intervention for self-management and lifestyle change for persons with type 2 diabetes, part 2: One-year results from the Norwegian randomized controlled trial renewing health. JMIR Mhealth Uhealth. 2014; 2(4): 1-15. PMID: 25499872 DOI: 10.2196/mhealth.3882 [PubMed]

116. Bereznak S, Ayres KM, Mechling LC, Alexander JL. Video self-prompting and mobile technology to increase daily living and vocational independence for students with autism spectrum disorders. Journal of Developmental and Physical Disabilities. 2012; 24(3): 269-85.

117. Aguilera A, Muñoz RF. Text messaging as an adjunct to CBT in low-income populations: A usability and feasibility pilot study. Prof Psychol Res Pr. 2011; 42(6): 472-8. PMID: 25525292 DOI: $10.1037 / \mathrm{a} 0025499$ [PubMed]

118. Weitzel JA, Bernhardt JM, Usdan S, Mays D, Glanz K. Using wireless handheld computers and tailored text messaging to reduce negative consequences of drinking alcohol. J Stud Alcohol Drugs. 2007; 68(4): 534-7. PMID: 17568957 DOI: 10.15288/jsad.2007.68.534 [PubMed]

119. Da Costa TM, Salomão PL, Martha AS, Pisa IT, Sigulem D. The impact of short message service text messages sent as appointment reminders to patients' cell phones at outpatient clinics in Sao Paulo, Brazil. Int J Med Inform. 2010; 79(1): 65-70. PMID: 19783204 DOI: 10.1016/j.ijmedinf.2009.09.001 [PubMed]

120. Naughton F, Prevost AT, Gilbert H, Sutton S. Randomized controlled trial evaluation of a tailored leaflet and SMS text message self-help intervention for pregnant smokers (MiQuit). Nicotine Tob Res. 2012; 14(5): 569-77. PMID: 22311960 DOI: $10.1093 / \mathrm{ntr} / \mathrm{ntr} 254$ [PubMed]

121. Haug S, Meyer C, Schorr G, Bauer S, John U. Continuous individual support of smoking cessation using text messaging: A pilot experimental study. Nicotine Tob Res. 2009; 11(8): 915-23. PMID: 19542517 DOI: $10.1093 /$ ntr/ntp084 [PubMed]

122. Newton KH, Wiltshire EJ, Elley CR. Pedometers and text messaging to increase physical activity: randomized controlled trial of adolescents with type 1 diabetes. Diabetes Care. 2009; 32(5): 813-5. PMID:

\section{DOI: $10.2337 / d c 08-1974$ [PubMed]}

123. Geraghty M, Glynn F, Amin M, Kinsella J. Patient mobile telephone'text'reminder: A novel way to reduce non-attendance at the ENT out-patient clinic. J Laryngol Otol. 2008; 122(3): 296-8. PMID: 17470313 DOI: $10.1017 / \mathrm{S} 0022215107007906$ [PubMed]

124. Word Health Organization. Obesity and overweight [Internet]. 2018 [cited: 5 Aug 2020]. Available from: https://www.who.int/news-room/factsheets/detail/obesity-and-overweight

125. Jolly K, Lewis A, Beach J, Denley J, Adab P, Deeks JJ, et al. Comparison of range of commercial or primary care led weight reduction programmes with minimal intervention control for weight loss in obesity: Lighten up randomised controlled trial. BMJ. 2011; 343: 1-16. PMID: 22053315 DOI: 10.1136/bmj.d6500 [PubMed]

126. Statista. Smoking: Statistics \& facts [Internet]. 2019 [cited: 5 Aug 2020]. Available from: https://www.statista.com/topics/1600/smoking/

127. Whittaker R, McRobbie H, Bullen C, Rodgers A, Gu Y. Mobile phone-based interventions for smoking cessation. Cochrane Database Syst Rev. 2016; 4: 1-45. PMID: $\quad 19821377 \quad$ DOI: 10.1002/14651858.CD006611.pub2 [PubMed]

128. Statista. Prevalence of tobacco smoking worldwide among those aged 15 years and older from 2000 to 2025 by age [Internet]. 2018 [cited: 5 Aug 2020]. Available

from: https://www.statista.com/statistics/937317/tobacc o-smoking-prevalence-globally-by-age/

129. Statista. Diabetes: Statistics \& facts [Internet]. 2019 [cited: 15 Aug 2020]. Available from: https://www.statista.com/topics/1723/diabetes/

130. Galaviz KI, Narayan KV, Lobelo F, Weber MB. Lifestyle and the prevention of Type 2 Diabetes: A status report. Am J Lifestyle Med. 2015; 12(1): 4-20. PMID: $30202378 \quad$ DOI: $\quad 10.1177 / 1559827615619159$ [PubMed]

131. Dave R, Davis R, Davies JS. The impact of multiple lifestyle interventions on remission of type 2 diabetes mellitus within a clinical setting. Obesity Medicine. 2019; 13: 59-64.

132. Statista. Number of people globally that suffered from select mental health or substance use disorders as of 2017 (in millions) [Internet]. 2019 [cited: 5 Aug 2020]. Available from: https://www.statista.com/statistics/979869/numbe r-of-people-with-mental-health-disorders-globally/

133. Global Statistics. The global HIV/AIDS epidemic [Internet]. 2019 [cited: 5 Aug 2020]. Available from: https://www.hiv.gov/hiv-basics/overview/dataand-trends/global-statistics

134. Word Health Organization. Immunization, vaccines and biologicals [Internet]. 2018 [cited: 6 Aug 2020]. Available from: https://www.who.int/immunization/diseases/hpv/ en/ 